\title{
Critical thinking and self-directed learning as an outcome of problem-based learning among nursing students in Egypt and Kingdom of Saudi Arabia
}

\author{
Eman Saleh Shahin ${ }^{1}$, Hanan Mohamed Tork ${ }^{2}$ \\ 1. Department of Medical Surgical Nursing, Faculty of Nursing, Port Said University, Egypt. 2. Department of pediatric \\ Nursing, Faculty of Nursing, Zagazig University, Egypt \\ Correspondence: Eman S. M. Shahin. Address: Medical-Surgical Nursing Department, Faculty of Nursing, Port Said \\ University, Egypt. Email: emanshaheen@yahoo.com.
}

Received: December 13, 2012 Accepted: March 10, $2013 \quad$ Online Published: May 21, 2013

DOI : 10.5430/jnep.v3n12p103 URL: http://dx.doi.org/10.5430/jnep.v3n12p103

\section{Abstract}

Background: Professional nurses need to develop critical thinking skills that will provide them with expertise in situationspecific problem solving.

Objectives: Describe the critical thinking and self directed learning abilities of the nursing students following Problembased learning approach in two countries; Egypt and Kingdom of Saudi Arabia KSA.

Method: A descriptive analytic research design was conducted. The study sample was consists of 60 students from first year in faculty of nursing divided by Egypt and Kingdom of Saudi Arabia: Instruments: The Self-Directed Learning Readiness Scale for Nursing Education (SDLRSNE) and Critical Thinking Dispositions Inventory were used. Results: This study revealed that the mean and standard deviation of total critical thinking was (102 \pm 14.45 and 101 \pm 16.44$)$ in KSA and Egypt respectively without significant difference between both countries. Moreover, the mean of total score of self direct learning was (162 \pm 27.04 and 157 \pm 23.64$)$ in KSA and Egypt respectively.

Conclusion: This study concluded that teaching with problem solving approach increase levels of critical thinking and self-directed learning in both countries without variation.

\section{Key words}

Critical thinking, Self-directed learning, Problem-based learning, Nursing students, Egypt and Kingdom of Saudi Arabia

\section{I ntroduction}

Nursing education is critical in assisting nursing students to integrate the theory and practice of nursing while helping them transform into professional nurses ${ }^{[1]}$. The linking of theory with practice can be attained through active learning, where students are encouraged to focus on problem solving, critical thinking, and teamwork ${ }^{[1]}$. Some nursing programs are using PBL (Problem-based learning) assist students to develop higher level of skills associated with professional nursing practice ${ }^{[2]}$. PBL is a student-centered approach to learning which enables the students to work cooperatively in small 
groups for seeking solutions to situations/problems ${ }^{[3]}$. Professional nurses need to develop critical thinking skills that will provide them with expertise in flexible, individualized, situation-specific problem solving ${ }^{[4]}$. However, nursing education strives to facilitate the development of students' critical thinking through the appropriate instructional approaches ${ }^{[5]}$.

Graduate nurses must be critical thinkers with the ability to manage complex situations ${ }^{[6]}$, and it is expected that nursing education will be help students to develop their critical thinking dispositions ${ }^{[7]}$. Nurse educators are therefore encouraged to evaluate courses and teaching strategies to ascertain whether critical thinking is reflected in their curricula ${ }^{[8,9]}$. PBL is a learning process, teaching strategy, and course-organizing method that enable students to work cooperatively in small groups to seek information and solutions to problems and situations ${ }^{[10,11]}$. PBL has been widely adopted in medical and nursing education and other health sciences (such as dentistry, occupational therapy, physical therapy, and public health) ${ }^{[10]}$. Additionally, many students considered the course to be challenging and motivated and identified the strengths of developing critical thinking, learning research skills creatively and personal growth ${ }^{[12,13]}$. The development of critical thinking is not only the basis of life-long learning but also the cornerstone of the professional growth ${ }^{[14]}$. Critical thinking competence has thus been designated as an outcome for judging the quality of nursing programs ${ }^{[15-18]}$ and for the development of clinical judgment ${ }^{[19-21]}$. The ability to think critically is also described as reducing the research-practice gap ${ }^{[22]}$ and fostering evidence-based nursing ${ }^{[23]}$.

\section{Literature review}

PBL is a teaching and learning method that empowers students to work through a process of actively participating in the learning process, working with peers in small groups to identify learning goals, engaging in self-study, discussing and applying new learning, and finally, integrating a variety of knowledge ${ }^{[24,25]}$. A quasi-experimental design with experimental and control groups to evaluate the effectiveness of PBL-CM in registered nursing (RN) students showed that PBL-CM increased students' critical-thinking skills and personal accountability for self-directed learning, and it would enhance the skills of independent study, reasoning, group interaction and active participation ${ }^{[26]}$.

Concept mapping (CM) is a representation of an individual's own ideas, interpreted in diagrammatic form ${ }^{[27]}$, that can also enhance learners' critical-thinking abilities ${ }^{[28]}$. Although PBL or CM mainly enhances the learners' critical-thinking and self-directed learning abilities, previous studies applied the PBL or CM teaching method solely and lacked the evidencebased data of long-term follow-up effectiveness ${ }^{[24,25,28]}$. Self-directed learning (SDL) has been defined as a process in which learners take the initiative and responsibility in identifying their own learning needs, formulating learning objectives, pursuing learning resources and strategies, and evaluating learning outcomes ${ }^{[29]}$. SDL integrates selfmanagement (management of actions and resources), self-monitoring (the process by which the learners monitor, evaluate and regulate their cognitive learning strategies), and motivation and volition in initiating and maintaining the efforts ${ }^{[30,31]}$.

Moreover, self-directed learning readiness is refers to the degree that learners possess the attitudes, abilities and necessary personality characteristics for self-directed learning. Readiness for SDL is individualized with varying degrees along a continuum ${ }^{[32]}$. Otherwise, advantages of SDL have been identified and included increased choice, confidence, autonomy, motivation and the development of skills for lifelong learning. In a self-directed learning process, students are encouraged to develop the ability to assess their knowledge deficit and then seek out relevant resources to help them address this deficit. They may use their own knowledge, explore the available resources, and make an informed judgment when selecting the solutions to problems ${ }^{[33]}$. The study of Rio (34) investigated 121 seniors in a human development course and found that after controlling for the possible confounding effects of age, gender, and ethnicity, self-directed learning readiness and curiosity uniquely predicted the classroom learning performance ${ }^{[35]}$. PBL is an approach to facilitate critical thinking (CT). This approach is a trend in higher education, particularly in university degree programs for health care professionals. One question to pursue is 'Has this approach demonstrated changes in students' CT? ${ }^{[36]}$. However, the majority of the literature supports the viewpoint that the PBL method enables the development of effective self-directed learning skills that encourage students to be responsible for their professional growth ${ }^{[25,37,38]}$. 


\section{Methods}

Descriptive analytic research design was conducted.

\subsection{Participants}

The study sample was consists of 60 students from first year in faculty of nursing divided by Egypt and Kingdom of Saudi Arabia (KSA). All students were invited to participate in the study through leaflet and brief discussion and/or explanation before available day courses.

\subsection{Ethical review}

Informed consent was obtained from the administrative authorities of the college of nursing, from which participants were voluntarily recruited in Qassim and Port Said University, in KSA and Egypt consecutively. The aims of the study were explained to the students and the participation was entirely voluntary. Students had an opportunity to determine their willingness or refusal to participate in the study. A signed informed consent was obtained from each student before data collection and confidentiality was ensured through using of code numbers. Students were appraised; all findings were reported as group results and submitted for publication.

\subsection{Instruments}

Two tools were used in this study. First one is named Self-Directed Learning Readiness Scale for Nursing Education (SDLRSNE) which developed by Fisher et al. ${ }^{[30]}$ to measure readiness for SDL in nursing students. The SDLRSNE is covering a total of 40 items across three subscales: Self-management (13 items), Desire for learning (12 items) and Self-control (15 items). The validity and reliability of the scale were supported by the results of several research studies $^{[39-43]}$. The value of the content validity index of Self-Directed Learning was tested by five experts and it was 0.915 . A measure of internal consistency (Cronbach's alpha) was 0.925 on the total scale. Students possessed readiness for SDL with a mean score of 157.72 (S.D. $=15.08,62.3 \%$ in high level, and $37.7 \%$ in low level) ${ }^{[44]}$.

The second tool is named Critical thinking inventory, which consists of 26 items including three subheading that named; engagement, cognitive maturity and innovativeness. Each of the 26 EMI constructs is measured on a five point likert scale with 1 representing "Strongly Disagree”, and 5 representing "Strongly Agree.” Scores for engagement, cognitive maturity and innovativeness constructs are independently calculated by summing the points obtained from an individual's responses to the respective items of each construct. To calculate an overall critical thinking disposition score, simply you can sum an individual's responses obtained from all 26 items. Reliability Estimates for EMI: Engagement, Cognitive Maturity, and Innovativeness were (0.906, 0.787 and 0.797) respectively, and the total score was 0.937. Typical Ranges for EMI; Engagement is 28 - 55, Maturity 16 - 40, Innovativeness 15 - 35 and total 59 - 130. Possible Ranges for EMI; is (11- 55) Engagement (8- 40) Maturity, (7 -35) Innovativeness 7 - 35 and total $26-130^{[44]}$.

\subsection{Data collection}

A socio-demographic form and PBL evaluation questionnaire (Arabic translated version) were used as tools for data collection. The data were collected in the middle of the final semester of the academic year. The questionnaires were distributed during class time and students were asked to complete and return it after the class was completed.

\subsection{Statistical analysis}

The data was managed, entered then; statistical analyses were conducted with SPSS software (version 19). Statistical testes used in this study were descriptive analysis as exploratory test (univariate analysis) to describe the sample characteristics and Chi-Square was also used to detect the relationship between using problem solving approach and critical thinking and self directed learning among newly student nurses in both countries. 


\section{Results}

This study revealed that the mean age of the total sample was 19.22 years old with SD of \pm 2.832 . Additionally, the mean age of Egypt sample was 18.6 years old with SD of \pm .814 while the mean age of QASSIM was 19.83 years old with SD of \pm 3.842 .

The study results revealed that mean of total selfed directed learning was 162 with SD of \pm 27.04 in KSA and the mean in Egypt was 157 with SD of \pm 23.63 . Additionally, the mean of total self management in KSA was 48.36 while in Egypt was 46.24. However the mean of total Desire learning was 52.7 in KSA and 48.3 in Egypt. On the other hand the mean of total self control was nearly the same in both countries and relatively high in both countries (see Table 1). Moreover, the study results found that no significant differences between both countries regarding levels and total score of self directed learning (see Table 2).

Table 1. Comparison between Egypt and KSA regarding Self Directed learning scale

\begin{tabular}{lllll}
\hline & Country & N & Mean & Std. Deviation \\
\hline \multirow{2}{*}{ Total self management } & KSA & 30 & 48.3667 & 14.52817 \\
& Egy & 29 & 46.2414 & 10.23877 \\
Total Desire learning & KSA & 30 & 52.7000 & 13.14416 \\
\multirow{2}{*}{ Total self control } & Egy & 28 & 48.2857 & 8.49774 \\
& KSA & 30 & 61.0000 & 8.21269 \\
Total Self Directed learning & Egy & 29 & 60.6552 & 8.80047 \\
& KSA & 30 & 162.0667 & 27.04267 \\
\hline
\end{tabular}

Note. KSA: Kingdom of Saudi Arabia; Egy: Egypt

Table 2. The difference between Egypt and Kingdom of Saudi Arabia regarding to Self Directed Learning using $t$-test

\begin{tabular}{|c|c|c|c|c|c|c|c|c|c|c|}
\hline & & \multicolumn{2}{|c|}{$\begin{array}{l}\text { Levene's Test } \\
\text { for Equality of } \\
\text { Variances } \\
\end{array}$} & \multicolumn{7}{|c|}{$t$-test for Equality of Means } \\
\hline & & \multirow[t]{2}{*}{$\mathbf{F}$} & \multirow[t]{2}{*}{ Sig. } & \multirow[t]{2}{*}{$t$} & \multirow[t]{2}{*}{ df } & \multirow[t]{2}{*}{$\begin{array}{l}\text { Sig. } \\
\text { (2-tailed) }\end{array}$} & \multirow[t]{2}{*}{$\begin{array}{l}\text { Mean } \\
\text { Difference }\end{array}$} & \multirow[t]{2}{*}{$\begin{array}{l}\text { Std. Error } \\
\text { Difference }\end{array}$} & \multicolumn{2}{|c|}{$\begin{array}{l}\text { 95\% Confidence } \\
\text { Interval of the } \\
\text { Difference }\end{array}$} \\
\hline & & & & & & & & & Lower & Upper \\
\hline \multirow{2}{*}{$\begin{array}{l}\text { Total self- } \\
\text { management }\end{array}$} & $\begin{array}{l}\text { Equal variances } \\
\text { assumed }\end{array}$ & .242 & .625 & .647 & 57 & .520 & 2.12529 & 3.28249 & $-4.44779-$ & 8.69837 \\
\hline & $\begin{array}{l}\text { Equal variances } \\
\text { not assumed }\end{array}$ & & & .651 & 52.187 & .518 & 2.12529 & 3.26351 & $-4.42287-$ & 8.67344 \\
\hline \multirow{2}{*}{$\begin{array}{l}\text { Total desire } \\
\text { learning }\end{array}$} & $\begin{array}{l}\text { Equal variances } \\
\text { assumed }\end{array}$ & .135 & .715 & 1.507 & 56 & .137 & 4.41429 & 2.92945 & $-1.45410-$ & 10.28267 \\
\hline & $\begin{array}{l}\text { Equal variances } \\
\text { not assumed }\end{array}$ & & & 1.529 & 50.016 & .133 & 4.41429 & 2.88755 & $-1.38549-$ & 10.21406 \\
\hline \multirow{2}{*}{$\begin{array}{l}\text { Total self- } \\
\text { control }\end{array}$} & $\begin{array}{l}\text { Equal variances } \\
\text { assumed }\end{array}$ & .245 & .623 & .156 & 57 & .877 & .34483 & 2.21522 & $-4.09108-$ & 4.78073 \\
\hline & $\begin{array}{l}\text { Equal variances } \\
\text { not assumed }\end{array}$ & & & .155 & 56.397 & .877 & .34483 & 2.21786 & $-4.09739-$ & 4.78705 \\
\hline \multirow{2}{*}{$\begin{array}{l}\text { Total delf } \\
\text { directed } \\
\text { learning }\end{array}$} & $\begin{array}{l}\text { Equal variances } \\
\text { assumed }\end{array}$ & .040 & .842 & .673 & 54 & .504 & 4.60513 & 6.83834 & $-9.10491-$ & 18.31516 \\
\hline & $\begin{array}{l}\text { Equal variances } \\
\text { not assumed }\end{array}$ & & & .680 & 53.993 & .499 & 4.60513 & 6.77205 & $-8.97205-$ & 18.18231 \\
\hline
\end{tabular}

Regarding the critical thinking score this study revealed that the mean of cognitive maturity, innovativeness, engagement and total critical thinking was nearly the same in both countries. Additionally, the study showed relatively high mean in all levels of critical thinking and in the total score of critical thinking disposition in both countries (see Table 3). Accordingly, 
there was no significant difference between both countries regarding all levels of critical thinking or the total score of it (see Table 4).

Table 3. Comparison between Egypt and KSA regarding critical thinking scale

\begin{tabular}{lllll}
\hline & Country & N & Mean & Std. Deviation \\
\hline \multirow{2}{*}{ Total cognitive } & KSA & 30 & 32.5000 & 9.00096 \\
\multirow{4}{*}{ Total innovativeness } & Egy & 29 & 32.2414 & 5.38288 \\
\multirow{4}{*}{ Total engagement } & KSA & 30 & 26.7667 & 3.37008 \\
& Egy & 30 & 26.7667 & 4.91783 \\
\multirow{2}{*}{ Total critical thinking } & KSA & 30 & 42.8667 & 8.19476 \\
& Egy & 29 & 41.9310 & 6.91236 \\
& KSA & 30 & 102.1333 & 14.45739 \\
& Egy & 28 & 101.3571 & 16.44343 \\
\hline
\end{tabular}

Note. KSA: Kingdom of Saudi Arabia; Egy: Egypt

Table 4. The difference between self directed learning levels in KSA and Egypt using T-test

\begin{tabular}{|c|c|c|c|c|c|c|c|c|c|c|}
\hline & & \multicolumn{2}{|c|}{$\begin{array}{l}\text { Levene's Test } \\
\text { for Equality of } \\
\text { Variances } \\
\end{array}$} & \multicolumn{7}{|c|}{$t$-test for Equality of Means } \\
\hline & & \multirow[t]{2}{*}{$\mathbf{F}$} & \multirow[t]{2}{*}{ Sig. } & \multirow[t]{2}{*}{$t$} & \multirow[t]{2}{*}{ df } & \multirow[t]{2}{*}{$\begin{array}{l}\text { Sig. } \\
\text { (2-tailed) }\end{array}$} & \multirow[t]{2}{*}{$\begin{array}{l}\text { Mean } \\
\text { Difference }\end{array}$} & \multirow[t]{2}{*}{$\begin{array}{l}\text { Std. Error } \\
\text { Difference }\end{array}$} & \multicolumn{2}{|c|}{$\begin{array}{l}\text { 95\% Confidence } \\
\text { Interval of the } \\
\text { Difference }\end{array}$} \\
\hline & & & & & & & & & Lower & Upper \\
\hline \multirow{2}{*}{$\begin{array}{l}\text { Total self- } \\
\text { management }\end{array}$} & $\begin{array}{l}\text { Equal variances } \\
\text { assumed }\end{array}$ & .004 & .953 & .133 & 57 & .894 & .25862 & 1.93922 & $-3.62461-$ & 4.14185 \\
\hline & $\begin{array}{l}\text { Equal variances } \\
\text { not assumed }\end{array}$ & & & .134 & 47.670 & .894 & .25862 & 1.92374 & $-3.6 .946-$ & 4.12670 \\
\hline \multirow{2}{*}{$\begin{array}{l}\text { Total Desire } \\
\text { learning }\end{array}$} & $\begin{array}{l}\text { Equal variances } \\
\text { assumed }\end{array}$ & 2.227 & .141 & .000 & 58 & 1.000 & 0.000 & 1.08846 & $-2.17879-$ & 2.17879 \\
\hline & $\begin{array}{l}\text { Equal variances } \\
\text { not assumed }\end{array}$ & & & .000 & 51.316 & 1.000 & .00000 & 1.08846 & $-2.18485-$ & 2.18485 \\
\hline \multirow{2}{*}{$\begin{array}{l}\text { Total self- } \\
\text { control }\end{array}$} & $\begin{array}{l}\text { Equal variances } \\
\text { assumed }\end{array}$ & .050 & .824 & .473 & 57 & .638 & .93563 & 1.97705 & $-3.02335-$ & 4.89461 \\
\hline & $\begin{array}{l}\text { Equal variances } \\
\text { not assumed }\end{array}$ & & & .475 & 55.987 & .637 & .93563 & 1.97131 & $-3.01341-$ & 4.88467 \\
\hline \multirow{2}{*}{$\begin{array}{l}\text { Total Self } \\
\text { Directed } \\
\text { learning }\end{array}$} & $\begin{array}{l}\text { Equal variances } \\
\text { assumed }\end{array}$ & .294 & .590 & .191 & 56 & .849 & .77619 & 4.05896 & $-7.35488-$ & 8.90726 \\
\hline & $\begin{array}{l}\text { Equal variances } \\
\text { not assumed }\end{array}$ & & & .190 & 53.895 & .850 & .77619 & 4.07724 & -7.39854- & 8.95092 \\
\hline
\end{tabular}

\section{Discussion}

The current study found that the mean of cognitive maturity, innovativeness, engagement and total critical thinking was nearly the same in both countries ${ }^{[26,32,42]}$ respectively and it was relatively high mean in all levels and total score of critical thinking disposition. These results could reflect the effect of Problem solving approach on developing critical thinking in all levels among student nurses in both countries. Agree with these results a qualitative study conducted in Australia about nursing students who completed a four-week PBL experience within a 'traditional' discipline-structured nursing program reported that they developed their critical thinking skills. They stated the PBL approach promoted critical thinking and problem solving, active participation in the learning process and the integration and synthesis of a variety of knowledge ${ }^{[24]}$. Moreover, a recent study ${ }^{[45]}$ used an experimental design where students in the first year of the BScN program were randomized to PBL or traditional education. The PBL students score was significantly higher on critical thinking compared to those educated in the traditional stream of the program. 
Additionally, Most previous descriptive studies showed that PBL enhanced the abilities of critical thinking (CT) ${ }^{[24,46-48]}$, self-directed learning (SDL) ${ }^{[46]}$, communication ${ }^{[48]}$ and active participation ${ }^{[24]}$. The quasi-experimental studies using pre-test-post-test method found that there was a significant improvement in CT after one-year (or two-semester) course) ${ }^{[45,49]}$. Nevertheless, Yuan et al. ${ }^{[50]}$ collected the available evidence in their review and reported no supportive evidence on developing nursing students' CT through PBL method.

Moreover, the current study results found that mean of total self directed learning was 162 in KSA and the mean in Egypt was 157 without significant difference between both countries, however the maximum total score of self directed learning is 200 and this means the sore of students nurse in both countries ranged from 78.5\% in Egypt to 81\% in KSA and this is relatively high score in both countries. This results could be also refer to the positively effect of problem based learning on self directed learning skills of the students in both countries. Consist with these results the study of Barrow ${ }^{\text {[51], who }}$ emphasized that the PBL method would enable nurses to develop inquiry, reasoning, interpersonal, and their life-long learning skills. Students also could be achieved the goals of self-directed learning, motivation, interaction among group members, communication, coordination, teamwork, and respect through $\mathrm{PBL}^{[51]}$. Furthermore, more than one literature review seems to support this view of point ${ }^{[37,38]}$.

Self-directed learning is an adult learning experience. It includes active learner involvement, collaborative faculty-student relationships, and enhancement of self-directed learning ${ }^{[52]}$. In summary, PBL-CM is not only to accumulate learners' knowledge but also to stimulate and reflect on learners' development of special skills and competencies. During the process of PBL-CM, in which learners are encouraged to think critically, they have opportunities to develop their sense of responsibility for their own growth. In every discussion of possible scenarios, learners take part in self- reflection and reflection on peers in the tutorial process. Learners are encouraged to present constructive criticism of themselves, their peers, and the tutor in the skill areas of critical thinking, self-directed learning, creativity, reasoning, independent study, communication, and interaction with the group in the dynamic group process ${ }^{[52-54]}$.

Teachers serve as facilitators. They stimulate students towards self-directed learning, and ensure that all students were involved in the process. They do not transmit expert knowledge to Students but probe students' knowledge by asking questions and encouraging specific kinds of cognitive activities. PBL requires students to spend more time and energy on conducting research, searching for information, sharing information, and commenting on information shared by their peers ${ }^{[53]}$.

\section{Conclusion}

This study concluded that critical thinking levels (Engagement, maturity and innovativeness) was relatively high in Egypt and KSA Universities. Additionally the total score of self directed learning and total of sub heading also was relatively high in both countries. Therefore it could be concluded from this study that teaching with problem solving approach could increase the level of critical thinking and self directed learning among student nurses in both countries without variation.

\section{References}

[1] Jerlock, M., Falk, K., Severinsson, E. Academic nursing education guidelines: tool for bridging the gap between theory, research and practice. Nursing and Health Science. 2003; 5: 219-228. PMid:12877723 http://dx.doi.org/10.1046/j.1442-2018.2003.00156.x

[2] Applin, H., Williams, B., Day, R., Buro, K. A comparison of competencies between problem-based learning and non-problembased graduate nurses. Nurse Education Today. 2011; 31: 129-134. PMid:20817332 http://dx.doi.org/10.1016/j.nedt.2010.05.003

[3] Hoban, J.D., Lawson, S.R., Mazmanian, P.E., Best, A.M., Seibel, H.R. The self directed learning readiness scale: a factor analysis study. Medical Education. 2005; 39(4): 370-379. PMid:15813759 http://dx.doi.org/10.1111/j.1365-2929.2005.02140.x

[4] Higgs, J., Jones, M. Clinical Reasoning in the Health Professions, 2nd ed. Butterworth-Heinemann, Oxford. 2000.

[5] Bowles, K. The relationship of critical-thinking skills and the clinical judgment skills of Baccalaureate nursing students. Journal of Nursing Education. 2000; 39(8): 373-376. PMid:11103976 
[6] Worrell J.A. \& Profetto-McGrath J. Critical thinking as an outcome of context-based learning among post RN students: a literature review. Nurse Education Today. 2007; 27: 420-426. PMid:16945453 http://dx.doi.org/10.1016/j.nedt.2006.07.004

[7] Daly W.M. Critical thinking as an outcome of nursing education. What is it? Why is it important to nursing practice? Journal of Advanced Nursing. 1998; 28(2): 323-331. PMid:9725729 http://dx.doi.org/10.1046/j.1365-2648.1998.00783.x

[8] Girot E.A. Graduate nurses: critical thinkers or better decisions makers? Journal of Advanced Nursing. 2000 ; $31(2)$ : $288-297$. PMid:10672085 http://dx.doi.org/10.1046/j.1365-2648.2000.01298.x

[9] Profetto-McGrath J. The relationship of critical thinking skills and critical thinking dispositions of baccalaureate nursing students. Journal of Advanced Nursing. 2003; 43(6): 569-577. PMid:12950562 http://dx.doi.org/10.1046/j.1365-2648.2003.02755.x

[10] Baker, C.M. Problem-based learning for nursing: integrating lessons from other disciplines with nursing experiences. Journal of Professional Nursing. 2000; 16(5): 258-266. PMid:11033935 http://dx.doi.org/10.1053/jpnu.2000.9461

[11] Beers, G.W. The effect of teaching method on objective test scores: Problem based learning versus lecture. Journal of Nursing Education. 2000; 44(7): 305-309. PMid:16094788

[12] Amos, E., White, M. J. Teaching tools: problem-based learning. Nurse Educator. 1998; 23: 11-14. PMid:9582794 http://dx.doi.org/10.1097/00006223-199803000-00009

[13] Edwards, N.C., Hebert, D., Moyer, A., Peterson, J., Sims-Jones, N., Verhovsek, H. Problem-based learning: preparing post-RN students for community-based care. Journal of Nursing Education. 1998; 37: 139-141. PMid:9535231

[14] Choi, H. The effects of problem-based learning on the meta-cognition, critical thinking, and problem solving process of nursing students. TaehanKAnhoHakhoe Chi. 2004; 34(5): 712- 721. PMid:15502436

[15] Facione, N.C., Facione, P.A. The “California Critical Thinking Skills Test”' and the National League for Nursing Accreditation Requirement in Critical Thinking. California Academic Press, Millbrae, CA. 1994.

[16] Maynard C.A. Relationship of critical thinking ability to professional nursing competence. Journal of Nursing Education. 1996; 35(1): 12-18. PMid:8926509

[17] Leppa, C. J. Standardized measures of critical thinking: Experience with the California critical thinking tests. Nurse Education. 1997; 22: 29-33. http://dx.doi.org/10.1097/00006223-199709000-00012

[18] Thorpe K. \& Loo R. Critical-thinking types among nursing and management undergraduates. Nurse Education Today. 2003; 23: 566-574. http://dx.doi.org/10.1016/S0260-6917(03)00102-3

[19] Facione, P.A. Critical thinking assessment in nursing education programs: an aggregate data analysis. California Academic Press, Millbrae, CA. 1997.

[20] Smith-Blair N. \& Neighbors M. Use of the critical thinking disposition inventory in critical care orientation. The Journal of Continuing Education in Nursing. 2000; 31(6): 251-256. PMid:11865857

[21] Stone C.A., Davidson L.J., Evans J.L. \& Hansen M.A. Validity evidence for using a general critical thinking test to measure nursing students’ critical thinking. Holistic Nursing Practice. 2001; 15(4): 65-74. PMid:12120497

[22] Seymour B., Kinn S. \& Sutherland N. Valuing both critical and creative thinking in clinical practice: narrowing the research practice gap? Journal of Advanced Nursing. 2003; 42(3): 288-296. PMid:12680973 http://dx.doi.org/10.1046/j.1365-2648.2003.02618.x

[23] Profetto-McGrath J. Critical thinking and evidence-based practice. Journal of Professional Nursing. 2005; $21(6)$ : 364-371. PMid:16311232 http://dx.doi.org/10.1016/j.profnurs.2005.10.002

[24] Cook, M., Moyle, K. Students’ evaluation of problem based learning. Nurse Education Today. 2002; 22: 330-339. PMid:12030754 http://dx.doi.org/10.1054/nedt.2001.0713

[25] Ozturk C., Muslu G.K. \&Dicle A. A comparison of problem based and traditional education on nursing students’ critical thinking dispositions. Nurse Education Today. 2008; 28: 627-632. PMid:18054412 http://dx.doi.org/10.1016/j.nedt.2007.10.001

[26] Tseng HC, Chou FH, Wang HH, Ko HK, Jian SY, Weng WC. The effectiveness of problem-based learning and concept mapping among Taiwanese registered nursing students. Nurse EducToday. 2011; 31: e41-6. PMid:21159411 http://dx.doi.org/10.1016/j.nedt.2010.11.020

[27] Irvine, L.M.C. Can concept mapping be used to promote meaningful learning in nurse education? Journal of Advanced Nursing. 1995; 21: 1175-1179. PMid:7665784 http://dx.doi.org/10.1046/j.1365-2648.1995.21061175.x

[28] Daley, B.J., Shaw, C.R., Balistrieri, T., Glasenapp, K., Piacentine, L. Concept maps: a strategy to teach and evaluate critical thinking. The Journal of Nursing Education. 1999; 38: 42-47. PMid:9921788

[29] Knowles, M.S. Self-Directed Learning: a Guide for Learners and Teachers. Globe Fearon, New Jersey. 1997.

[30] Fisher, M., King, J., Tague, G. The development of a self-directed learning readiness scale for nursing education. Nurse Education Today. 2001; 21: 516-525. PMid:11559005 http://dx.doi.org/10.1054/nedt.2001.0589

[31] O’Shea, E. Self-directed learning in nurse education: a review of the literature. Journal of Advanced Nursing. 2003 ; 43 (1): $62-70$. PMid:12801397 http://dx.doi.org/10.1046/j.1365-2648.2003.02673.x 
[32] Wiley, K. Effects of a self-directed learning project and preference for structure on self-directed learning readiness. Nursing Research. 1983; 32(3): 181-185. PMid:6551780 http://dx.doi.org/10.1097/00006199-198305000-00011

[33] Karimi, R., Arendt, C.S., Cawley, P., Buhler, A.V., Elbarbry, F., Roberts, S.C. Learning bridge: curricular integration of didactic and experiential education. American Journal of Pharmaceutical Education. 2010; 74 (3): Article 48. PMid:20498741 http://dx.doi.org/10.5688/aj740348

[34] Reio, T.G. Prior knowledge, self-directed learning readiness and curiosity: antecedents to classroom learning performance. International Journal of Self Directed Learning. 2004; 1(1): 18-25.

[35] Yuan H., Williams B.A., Fang J.B., Pang D. Chinese baccalaureate nursing students' readiness for self-directed learning, Nurse Education Today, Article in Press. 2011.

[36] Choon-EngGwee M. Globalization of Problem-Based Learning (Pbl): Cross - Cultural Implications, Kaohsiung J Med Sci. 2008; 24(3 Suppl): S14-22. http://dx.doi.org/10.1016/S1607-551X(08)70089-5

[37] Bernstein, P., Tipping, J., Bertowitz, K., Skinner, H.A. Shifting students and faculty to a PBL curriculum: attitudes changed and lessons learned. Academic Medicine. 1995; 70: 245-247. PMid:7873016 http://dx.doi.org/10.1097/00001888-199503000-00019

[38] Caplow, J.A., Donaldson, J.F., Kardash, C., Hosokawa, M. Learning in a problem based medical curriculum: students' conceptions. Medical Education. 1997; 31: 440-447. PMid:9463647 http://dx.doi.org/10.1046/j.1365-2923.1997.00700.x

[39] Hoban, J.D., Lawson, S.R., Mazmanian, P.E., Best, A.M., Seibel, H.R. The self directed learning readiness scale: a factor analysis study. Medical Education. 2005; 39 (4): 370-379. PMid:15813759 http://dx.doi.org/10.1111/j.1365-2929.2005.02140.x

[40] Bridges, P.H., Bierema, L.L., and Valentine, T. The propensity to adopt evidence based practice among physical therapists. BMC Health Services Research. 2007; 7: 103-112. PMid:17615076 http://dx.doi.org/10.1186/1472-6963-7-103

[41] Smedley, A. The self-directed learning readiness of first year bachelor of nursing students. Journal of Research in Nursing. 2007; 12 (4): 373-385. http://dx.doi.org/10.1177/1744987107077532

[42] Hendry, G.D., Ginns, P. Readiness for self-directed learning: validation of a new scale with medical students. Medical Teacher, in press. 2009. http://dx.doi.org/10.1080/01421590802520899.

[43] Fisher M.J., King J. The self-directed learning readiness scale for nursing education revisited: A confirmatory factor analysis, Nurse Education Today. 2010; 30: 44-48. PMid:19541394 http://dx.doi.org/10.1016/j.nedt.2009.05.020

[44] Irani, T., Rudd, R., Gallo, M., Rickett s, J., Friedel, C., \& Rhoades, E. Critical thinking instrumentation manual. 2007. Available from: http://step.ufl.edu/resources/critical_thinking/ctmanual.pdf.

[45] Tiwari, A., Lai, P., So, M., Yeun, K. A comparison of the effects of problem-based learning and lecturing on the development of students' critical thinking. Medical Education. 2006; 40: 547-554. PMid:16700770 http://dx.doi.org/10.1111/j.1365-2929.2006.02481.x

[46] Celia, L.M., Gordon, P.R. Using problem-based learning to promote critical thinking in an orientation program for novice nurses. Journal Nurses Staff Development. 2011; 17 (1): 12-17. PMid:12759935 http://dx.doi.org/10.1097/00124645-200101000-00002

[47] Joe, W.M., Elizabeth, A. Problem-based learning: an outcomes study. Nurse Education. 1999; 24 (2): 33-36. http://dx.doi.org/10.1097/00006223-199903000-00011

[48] Morales-Mann, E., Kaitell, C.A. Problem-based learning in a new Canadian curriculum. Journal of Advanced Nursing. 2001; 33(1): 13-19. PMid:11155104 http://dx.doi.org/10.1046/j.1365-2648.2001.01633.x

[49] Day, R.A., Williams, B.A. Development of critical thinking through problem-based learning: a pilot study. Journal on Excellening in College Teaching. 2002; 11 (2 \& 3): 203-226.

[50] Yuan H., Williams B.A., Fan L. A systematic review of selected evidence on developing nursing students' critical thinking through problem-based learning, Nurse Education Today. 2008; 28: 657-663. PMid:18267348 http://dx.doi.org/10.1016/j.nedt.2007.12.006

[51] Barrows, H.S. The essentials of problem-based learning. Journal of Dental Education. 1998; 62(9): 630-633. PMid:9789484

[52] Williams, B. Self direction in a problem based learning program. Nurse Education Today. 2004; 24: 277-285. PMid:15110437 http://dx.doi.org/10.1016/j.nedt.2004.01.008

[53] Rideout, W., Carpio, B. The problem-based learning model of nursing education. In: Rideout, E. (Ed.), Transforming Nursing Education through Problem-based Learning. Jones and Bartlett Publishers, Canada, Mississauga. 2001: 21-49.

[54] White, M.J., Amos, E., Kouzekanani, K., 1999. Problem-based learning: an outcome study. Nurse Educator 24 (2), $33-36$. PMid:10410023 http://dx.doi.org/10.1097/00006223-199903000-00011 